\title{
Website jeruq.com sebagai alat evaluasi pembelajaran matematika pada masa pandemi Covid-19
}

\author{
Iffa Hanifah Rahman, Nanang Priatna \\ Pendidikan Matematika, Universitas Pendidikan Indonesia, Bandung \\ *iffahanifahrahman@upi.edu
}

Received: 30 April 2021; Accepted: o9 Juni 2021; Published: 30 Juni 2021

\begin{abstract}
Abstrak
Salah satu upaya pemerintah untuk memutus rantai virus covid-19 yaitu dengan menerapkan pembelajaran jarakjauh (daring) sehingga evaluasi pembelajaran pun dilakukan secara online. Penelitian ini dilakukan untuk mendeskripsikan kelebihan dan kekurangan website jeruq.com sebagai alat evaluasi pembelajaran daring selama masa pandemi Covid-19. Penelitian ini dilakukan di salah satu SMK di Kabupaten Bandung Barat dengan subjek yaitu siswa sebanyak 20 orang dan satu orang guru. Penelitian ini menggunakan pendekatan kualitatif deskriptif dengan teknik pengumpulan data berupa tes, wawancara, angket, dan dokumentasi. Hasil penelitian ini menunjukan respon yang baik dari siswa dan guru pada website jeruq.com. Kelebihan pada website ini yaitu tampilannya mudah dimengerti dan mampu menghemat waktu. Sehingga website ini dapat dijadikan sebagai alat evaluasi pembelajaran daring.
\end{abstract}

Kata kunci: Jeruq, Covid-19, Evaluasi Pembelajaran, Pembelajaran Daring

\begin{abstract}
One of the government's efforts to break the chain of the Covid-19 virus is by implementing distance learning (online) so that learning evaluations are carried out online. This research was conducted to describe the advantages and disadvantages of the jeruq.com website as an online learning evaluation tool during the Covid-19 pandemic. This research was conducted in a high school in Bandung Regency with the subject of 20 students and one teacher. This study used a descriptive qualitative approach with data collection techniques in the form of tests, interviews, questionnaires, and documentation. The results of this study show a good response from students and teachers on the website jeruq.com. The advantages of this website are that it looks easy to understand and can save time. So that this website can be used as an online learning evaluation tool.
\end{abstract}

Keywords: Jeruq, Covid-19, Learning Evaluation, Online Learning 


\section{PENDAHULUAN}

Pada masa Covid-19, Indonesia telah melakukan berbagai upaya dan usaha di segala bidang serta berbagai inovasi baru telah dimunculkan untuk memutuskan rantai penyebaran virus Covid-19. Salah satu upaya yang dilakukan tersebut dengan mengadakannya work from home dan study from home. Menteri pendidikan Indonesia Nadiem Makarim melakukan sebuah upaya untuk lembaga pendidikan yaitu dengan melakukan study from home atau pembelajaran jarak jauh (daring). Menurut hasil penelitian, Indonesia menduduki peringkat kelima dengan pengguna internet terbesar di dunia (Ngafifah, 2020). Berdasarkan Balai Statistik Indonesia, terdapat 50\% dari keseluruhan penduduk Indonesia yang merupakan pengguna internet dan mayoritasnya adalah para pelajar (Efendi, 2018). Pada awal tahun 2021, pengguna intenet di Indonesia mengalami kenaikan sebesar 15,5\% dari awal tahun sebelumnya (Riyanto, 2021). Tak dapat dipungkiri bahwa kenaikan tersebut meningkat salah satunya karena adanya pembelajaran secara daring (online).

Saat ini di Asia Tenggara, Indonesia menduduki sebagai Negara yang memiliki kasus Covid-19 terbanyak. Sejak bulan Maret 2020 kasus Covid-19 di Indonesia mulai meningkat sampai pada tanggal 20 Juli mecapai 43.803 kasus (Irawati \& Jonatan, 2020), sehingga secara nasional kegiatan belajar siswa dilakukan di rumah dengan menerapkan sistem pembelajaran jarak jauh (daring). Tidak hanya Indonesia yang menetapkan sistem pembelajaran di rumah, tetapi seluruh negara di dunia melakukan sistem pembelajaran yang sama. Tujuan diberlakukannya pembelajaran jarak jauh yaitu untuk memutus mata rantai virus Covid-19.

Salah satu upaya sekolah dalam mengikuti aturan dari Kementrian Pendidikan dan Kebudayaan diantaranya yaitu mengharuskan lembaga pendidikan di Indonesia yang melakukan pembelajaran jarak jauh, salah satunya ialah SMK A yang terletak di Kabupaten Bandung Barat. SMK A melakukan pembelajaran jarak jauh dengan proses pembelajaran yang dilakukan secara online. Pembelajaran online yang dilakukan secara daring perlu mempertahankan proses komunikasi secara intens serta terarah dengan tujuan mencapai semua indicator pembelajaran yang telah ditetapkan (Ngafifah, 2020). Pelaksanaan pembelajaran yang baik sangat memerlukan adanya interaksi dari seluruh komponen yang terlibat dalam proses pembelajaran, baik antara siswa bersama guru ataupun antar siswa. Selama adanya pandemi Covid-19 terjadi, pembelajaran tetap dituntut untuk selalu terlaksana dengan baik supaya materi pelajaran dapat tersampaikan seluruhnya dengan baik, salah satunya pelajaran matematika.

Pelajaran matematika dikenal dengan pelajaran bersifat abstrak, sehingga dalam proses pembelajaran dibutuhkan strategi yang sesuai diwaktu mengajarkan matematika agar siswa bisa dengan mudah memahami suatu konsep dalam materi. Didalam proses pembelajaran sampai sekarang ini, sebagian besar siswa mengalami kesulitan disaat belajar matematika. Ada juga yang merasa dengan adanya pandemi seperti sekarang ini mereka jadi kurang efektif dalam menerima pembelajaran secara daring sehingga menyebabkan hasil belajar yang menurun (Lestari \& Putra, 2020). Semua hal ini tidak hanya karena kesalahan siswa tapi bisa juga disebabkan oleh penggunaan media atau alat evaluasi pembelajaran yang tidak tepat.

Dalam perkembangan zaman saat ini, dunia pendidikan akan menyongsong perubahan yang dipengaruhi oleh berkembangnya teknologi. Disaat era teknologi saat ini, terdapat media dan alat evaluasi yang menggeser pembelajaran yang biasanya dilakukan tatap muka di kelas secara langsung antara siswa bersama guru menjadi tanpa adanya tatap muka langsung (Lestari \& Putra, 2020) yang dikenal sebagai pembelajaran jarak jauh. Penggunaan pembelajaran jarak jauh 
(daring) di sekolah pada masa pandemi Covid19, seluruh tenaga pendidik diwajibkan untuk menggunakan pembelajaran berbasis teknologi. Perubahan cara pembelajaran ini tentunya menuntut kemampuan guru maupun siswa dalam menggunakan aplikasi atau software teknologi informasi untuk menunjang pembelajaran daring.

Aplikasi atau software berbasis teknologi menjadi hal yang cukup penting dalam pembelajaran daring sehingga guru atau tenaga pendidikan perlu menguasai teknologi guna terciptanya pembelajaran yang efektif. Pengaruh teknologi sudah banyak dirasakan oleh berbagi pihak di dunia pendidikan, terutama aplikasi atau software yang dapat digunakan secara gratis sehingga mampu membantu guru dan siswa (Wulandari, Maswani, \& Khotimah, 2019). Banyak aplikasi ataupun software yang berbasis teknologi informasi yang dapat digunakan untuk proses pembelajaran daring, salah satunya adalah website jeruq.com. Software website ini merupakan layanan yang dapat dimanfaatkan dalam menunjang proses pembelajaran terutama dalam hal evaluasi pembelajaran, karena website jeruq.com memiliki fitur untuk membuat ujian secara daring. Website jeruq.com ini dapat digunakan secara gratis untuk pendidikan. Namun, masih banyak yang belum mengetahui terkait website jeruq.com ini.

Jeruq.com merupakan sebuah website karya anak bangsa yang dapat digunakan untuk membuat kelas dan soal secara online (Jeruq, 2021) dengan langkah-langkahnya yang cukup mudah. Untuk dapat membuat kelas dan soal pada website ini, pengguna wajib membuat akun terlebih dahulu atau dapat masuk menggunakan e-mail yang telah dimiliki. Website ini merupakan website yang gratis dengan koneksi yang ringan sehingga akan mudah untuk diakses saat melakukan pembelajaran.

\section{METODE}

Pendekatan pada penelitian ini menggunakan pendekatan kualitatif deskriptif. Penelitian ini dilakukan di salah satu sekolah atau lembaga pendidikan pada jenjang sekolah menengah kejuruan yaitu SMK A yang terletak di Kabupaten Bandung Barat. Subjek penelitian yaitu siswa kelas $\mathrm{X}$ sebanyak 20 orang dan 1 orang guru yang mengajar 20 siswa kelas $\mathrm{X}$ di SMK tersebut.

Teknik pengumpulan data menggunakan soal tes, wawancara, angket, dan dokumentasi. Soal tes yang diberikan menggunakan website jeruq.com yang terdiri dari 10 soal pilihan ganda dan 5 soal uraian singkat dengan materi barisan dan deret aritmatika. Berikut tahapannya.

\section{Tahap proses (memiliki akun)}

Website jeruq.com mengharuskan peneliti memiliki akun terlebih dahulu. Terdapat dua pilihan pembuatan akun yaitu secara manual dan menggunakan akun google. Karena peneliti sudah memiliki akun google, fitur Sign in with google dipilih peneliti agar lebih efisien sehingga langkah selanjutnya untuk mengakses jeruq.com lebih mudah.

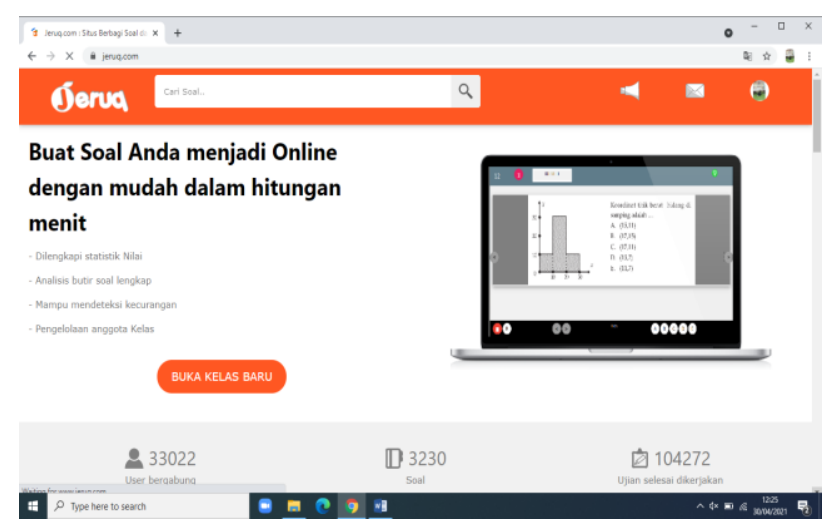

Gambar 1. Tampilan Website Jeruq.com

Gambar 1 merupakan tampilan halaman awal pada website jeruq.com. Jika sebelumnya sudah membuat e-mail maka dapat memilih fitur masuk menggunakan email, tetapi jika tidak maka sebaiknya pilih daftar dan melengkapi data yang tersedia. 


\section{Tahap pembuatan soal}

Soal yang dapat dibuat menggunakan website jeruq.com hanya soal berbentuk pilihan ganda dan uraian singkat, sehingga kedua jenis soal tersebut dibuat peneliti pada Microsoft Office Word agar dapat diunggah pada website jeruq.com. Selanjutnya kelas dibuat peneliti bersamaan dengan dimasukkannya data yang diperlukan pada fitur buat kelas sebagai ruang untuk mengunggah soal.

Post image, fitur yang dipilih peneliti untuk mengunggah soal yang telah dibuat. Selanjutnya, ketarangan soal ditambahkan peneliti sehingga soal siap untuk dipublikasikan.

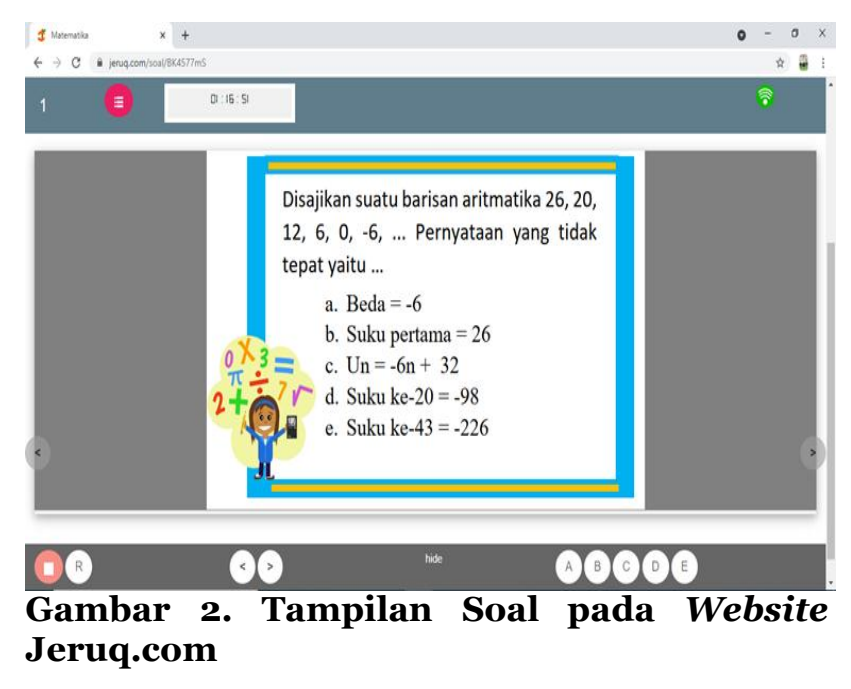

3. Tahap publikasi

Soal dipublikasikan peneliti dengan dibagikannya alamat website jeruq.com yang telah terdapat unggahan soal kepada siswa yang selanjutnya alamat website dibuka oleh siswa pada website jeruq.com melalui aplikasi peramban telepon pintar atau komputer personal.

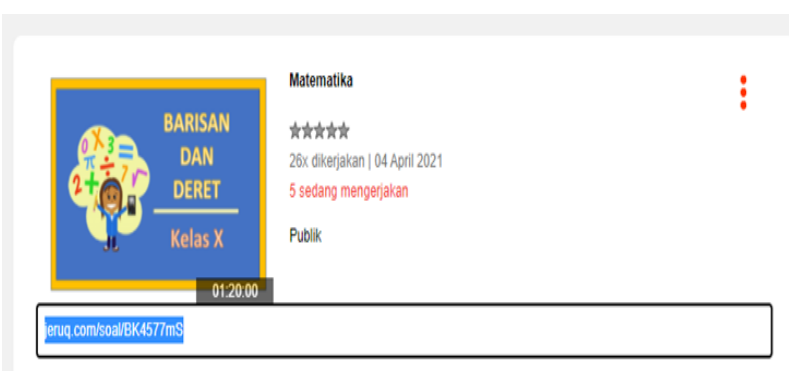

Gambar 3. Link Soal pada Website Jeruq.com

Gambar 3 menunjukan tempat link soal yang dapat di copy paste untuk membagikan soal kepada responden atau siswa. Ketika siswa membuka link tersebut maka akan otomatis masuk pada halaman soal dan dapat memulai langkah penyelesaian.

Hasil tes siswa akan langsung terlihat pada website jeruq.com dengan jumlah waktu penyelesaian yang diperoleh. Tetapi peneliti akan mengklasifikasikan hasil tes siswa tersebut berdasarkan tingkat kemampuan menjadi tinggi, sedang, dan rendah menggunakan formula sebagai berikut.

$\stackrel{\substack{\text { Mean }+ \text { SD }>\\ \text { Mean-SD s.d. Mean+SD }}}{\longrightarrow} \begin{gathered}\text { Kemampuan Tinggi } \\ \text { Kemampuan } \\ \text { Sedang }\end{gathered}$

$<$ Mean - SD

Kemampuan

Rendah

(Furqon, 2014)

Sedangkan wawancara dilakukan untuk mengetahui respon guru terkait penggunaan website jeruq.com. Sebelum melakukan wawancara, peneliti menjelaskan terlebih dahulu cara penggunaan, pembuatan kelas, pembuatan soal dan fitur-fitur yang ada pada website jeruq.com ini. Angket digunakan untuk mengetahui respon siswa dengan bentuk angket tertutup berupa angket skala likert. Peneliti menggunakan hasil jawaban angket yang dianalisis menggunakan perhitungan skor rata-rata pada setiap aspek, kemudian 
diklasifikasikan seperti pada Tabel 1 menjadi sangat baik, baik, cukup, kurang, dan sangat kurang untuk memperoleh kesimpulan.

Tabel 1. Klasifikasi Penilaian Respon Siswa

\begin{tabular}{cc}
\hline $\begin{array}{c}\text { Interval Skor Rata- } \\
\text { Rata }\end{array}$ & Klasifikasi \\
\hline $\boldsymbol{x}>\mathbf{4 . 2}$ & Sangat Baik \\
\hline $\mathbf{3 . 4}<\boldsymbol{x} \leq \mathbf{4 . 2}$ & Baik \\
\hline $\mathbf{2 . 6}<\boldsymbol{x} \leq \mathbf{3 . 4}$ & Cukup \\
$\mathbf{1 . 8}<\boldsymbol{x} \leq \mathbf{2 . 6}$ & Kurang \\
\hline $\boldsymbol{x} \leq \mathbf{1 . 8}$ & Sangat Kurang \\
\hline & (Nashiroh, 2014)
\end{tabular}

Pada penelitian ini, dokumentasi digunakan untuk melengkapi langkah-langkah dalam penggunaan website jeruq.com. Teknik analisis data yang digunakan pada penelitian ini adalah reduksi data (data reduction), penyajian data (data display), penarikan kesimpulan, dan verifikasi kemudian dilengkapi dengan teknik triangulasi.

\section{HASIL DAN PEMBAHASAN}

Website jeruq.com merupakan salah satu website yang dapat dimanfaatkan dalam pendidikan. Website jeruq.com ini memiliki template yang mudah dipahami sehingga dapat digunakan sebagai alat evaluasi pembelajaran karena dapat membuat soal dengan cukup mudah dan hasil penilaiannya dapat langsung diketahui.

Saat siswa diberikan link soal tes, tampilan yang sama akan muncul baik dibuka menggunakan smartphone ataupun laptop. Tampilan tersebut merupakan cover dari soal tes yang diberikan.

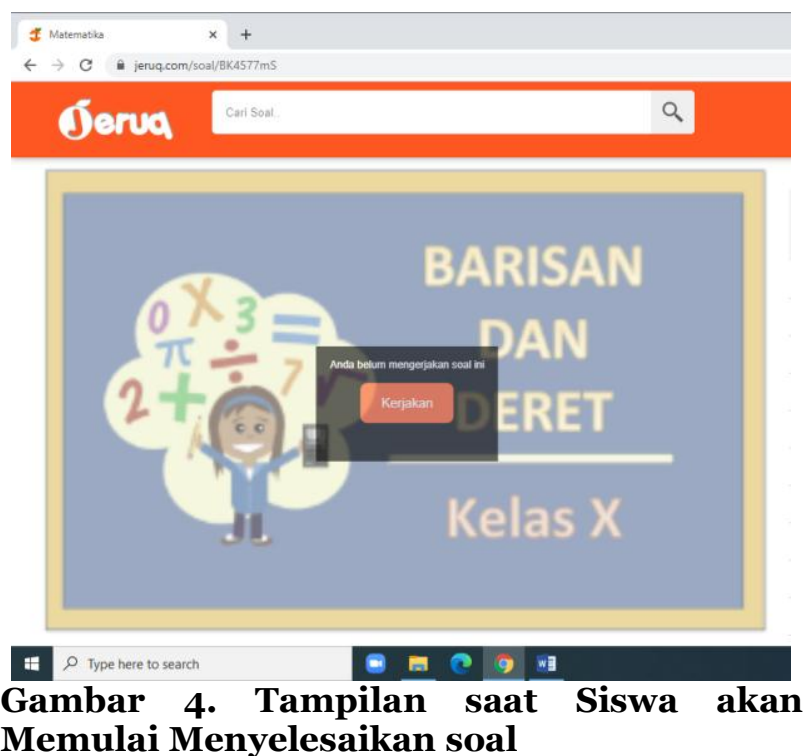

Gambar 4 merupakan tampilan ketika siswa masuk pada link soal yang diberikan. Siswa dapat langsung mengerjakan soal dengan klik mulai/kerjakan dan waktu penyelesaian akan terhitung saat siswa klik tombol tersebut.

\section{Hasil tes siswa pada materi barisan dan deret aritmatika menggunakan website jeruq.com}

Data yang akan diuraikan pada bagian ini merupakan hasil tes yang diperoleh dari 20 siswa. Tes ini digunakan untuk memberikan latihan terkait materi barisan dan deret menggunakan website jeruq.com, sehingga siswa mendapatkan pengalaman menyelesaikan latihan menggunakan website jeruq.com ini. Hasil tes ditampilkan dengan bentuk klasifikasi tingkat kemampuan siswa yang sudah dibagi menjadi tiga tingkat kemampuan sebagai berikut.

Tabel 2. Hasil Klasifikasi Kemampuan Siswa

\begin{tabular}{ccc}
$\begin{array}{c}\text { Klasifikasi } \\
\text { Tingkat } \\
\text { Kemampuan }\end{array}$ & Jumlah & Persentase \\
\hline Tinggi & 3 & $\mathbf{1 5 \%}$ \\
Sedang & 15 & $75 \%$ \\
\hline
\end{tabular}


Website jeruq.com sebagai alat evaluasi pembelajaran matematika pada masa pandemi Covid-19

\section{Klasifikasi \\ Tingkat \\ Kemampuan}

\section{Jumlah Persentase}

2

$10 \%$

Berdasarkan Tabel 2, diperoleh informasi bahwa siswa yang termasuk pada klasifikasi kemampuan tinggi sebanyak 3 orang sehingga diperoleh persentase sebanyak 15\%. Sedangkan siswa yang termasuk pada kemampuan sedang sebanyak 15 orang dengan persentase $75 \%$ dan kemampuan rendah sebanyak 2 orang dengan persentase sebanyak $10 \%$.

\section{Respon siswa terhadap penggunaan website jeruq.com sebagai alat evaluasi}

Salah satu faktor terpenting dalam kesuksesan menggunakan alat evaluasi pembelajaran website jeruq.com adalah siswa. Selama pembelajaran daring, siswa sudah terbiasa menggunakan software atau teknologi lainnya karena pembelajaran dilakukan secara online. Sehingga siswa sudah mampu mengoperasikan smartphone dan sudah memiliki $e$-mail (Lestari \& Putra, 2020). Data hasil respon siswa diperoleh dari hasil angket yang telah diberikan kepada siswa setelah mengerjakan soal menggunakan website jeruq.com. Berikut ini merupakan hasil respon siswa.

Tabel 3. Hasil Respon Siswa

\begin{tabular}{clc}
\hline No & \multicolumn{1}{c}{ Aspek } & $\begin{array}{c}\text { Skor } \\
\text { Rata- } \\
\text { Rata }\end{array}$ \\
\hline $\mathbf{1}$ & $\begin{array}{l}\text { Siswa merasa senang } \\
\text { mengerjakan soal } \\
\text { menggunakan website } \\
\text { jeruq.com }\end{array}$ & 4.35 \\
\hline $\mathbf{2}$ & $\begin{array}{l}\text { Akses masuk pada website } \\
\text { jeruq.com mudah }\end{array}$ & 4.35 \\
\hline $\mathbf{3}$ & $\begin{array}{l}\text { Tampilan website jeruq.com } \\
\text { mudah dimengerti }\end{array}$ & 4.15 \\
\hline $\mathbf{4}$ & $\begin{array}{l}\text { Penggunaan website } \\
\text { jeruq.com dapat }\end{array}$ & 4.35 \\
\hline
\end{tabular}

\begin{tabular}{|c|c|c|}
\hline No & Aspek & $\begin{array}{c}\text { Skor } \\
\text { Rata- } \\
\text { Rata }\end{array}$ \\
\hline & \multicolumn{2}{|l|}{ mengefisiensikan waktu } \\
\hline 5 & $\begin{array}{l}\text { Penggunaan website } \\
\text { jeruq.com dapat menghemat } \\
\text { kertas }\end{array}$ & 4.45 \\
\hline 6 & $\begin{array}{l}\text { Tidak ada eror saat } \\
\text { menggunakan website } \\
\text { jeruq.com }\end{array}$ & $4 \cdot 3$ \\
\hline & Rata Rata Akhir & 4.32 \\
\hline & Kategori & $\begin{array}{c}\text { Sangat } \\
\text { Baik }\end{array}$ \\
\hline
\end{tabular}

Berdasarkan hasil pada Tabel 3, diperoleh bahwa respon siswa saat mengerjakan soal menggunakan website jeruq.com memiliki rata-rata sebesar 4.325 dengan kategori sangat baik. Siswa merasa senang menggunakan website jeruq.com pada pembelajaran mereka, sehingga dapat mempermudah siswa untuk menerima materi. Hal ini sejalan dengan pendapat Nurrita (2018) yang mengungkapkan bahwa jika siswa sudah merasa senang melaksanakan suatu pembelajaran, maka materi yang disampaikan akan mudah diterima dengan baik. Selain itu, menurut Arianti (2017) menyatakan fasilitas belajar yang menyenangkan maka dapat memberikan dampak positif bagi proses pembelajaran. Sehingga rasa senang siswa saat menggunakan website jeruq.com dapat menjadi hal positif agar siswa dapat tertarik dan bersemangat saat melaksanakan ujian atau latihan.

Akses masuk dan tampilan mudah dimengerti merupakan salah satu aspek yang penting saat menggunakan alat evaluasi secara online (Sianipar, 2019). Karena jika siswa merasa kesulitan menggunakan alat evaluasi tersebut, maka siswa tidak akan bersemangat dan malas sebelum soal tes diselesaikan seluruhnya. Hal ini sejalan dengan Warif (2019) bahwa kesulitan yang dirasakan oleh siswa saat 
melakukan pembelajaran akan memunculkan rasa malas yang berdampak negatif pada pembelajaran tersebut. Penilaian dilakukan secara online dapat membuat siswa bersemangat sehingga dapat meningkatkan nilai siswa dibandingkan dengan penilaian secara konvensional (Suryanovika, 2020).

Selain 6 aspek yang ada pada angket respon siswa, siswa juga diberikan satu pernyataan tambahan pada angket tersebut terkait masalah yang dihadapi oleh siswa saat menggunakan website jeruq.com. Karena meskipun pembelajaran ataupun penilaian dilakukan secara online, didalam pelaksanaanya masih banyak ditemukan kendala (Bafadal \& Triansyah, 2020) begitupun pada penggunaan website jeruq.com. Berikut ini merupakan beberapa masalah yang dihadapi oleh siswa saat menggunakan website jeruq.com.

Tabel 4. Masalah yang Dihadapi Siswa saat Menggunakan Website Jeruq.com

\section{Masalah yang dihadapi Jumlah saat menggunakan website jeruq.com}

\begin{tabular}{lc}
\hline $\begin{array}{l}\text { Tidak ada masalah yang } \\
\text { berarti }\end{array}$ & 10 \\
Kehabisan paket internet & 3 \\
$\begin{array}{l}\text { Baterai handphone mengalami } \\
\text { kerusakan atau tiba-tiba mati }\end{array}$ & 0 \\
$\begin{array}{l}\text { Tidak sengaja mengeluarkan } \\
\text { Website Jeruq.com }\end{array}$ & 1 \\
$\begin{array}{l}\text { Link tidak bisa dibuka } \\
\text { Merasa tegang }\end{array}$ & 2 \\
$\begin{array}{l}\text { Tidak sengaja menekan } \\
\text { tombol "kirim" } \\
\text { Sinyal internet tiba-tiba mati }\end{array}$ & 2 \\
$\quad$ Jumlah Keseluruhan & 20 \\
\hline
\end{tabular}

Pada Tabel 4 memberikan informasi bahwa 10 siswa tidak mengalami masalah yang berarti saat mengerjakan soal menggunakan website jeruq.com. Terdapat beberapa masalah yang dihadapi oleh siswa saat mengerjakan soal menggunakan website ini, tetapi tidak ada siswa yang mengalami masalah terkait baterai handphone dan tidak sengaja menekan tombol kirim. Permasalahan yang ada dikarenakan sinyal internet dan kehabisan paket internet. Hal ini sudah menjadi permasalah umum yang dialami beberapa siswa ketika pembelajaran dilakukan secara online. Siswa mengalami kesulitan sinyal untuk selalu terhubung ke internet dikarenakan beberapa siswa yang memiliki rumah yang jauh dari perkotaan (Astini, 2020) dan paket internet yang terbilang mahal (Novita \& Hutasuhut, 2020). Masalah-masalah yang dihadapi siswa tersebut dapat diatasi sehingga siswa dapat menyelesaikan soal sampai selesai menggunakan website jeruq.com.

\section{Respon guru terhadap penggunaan website jeruq.com sebagai alat evaluasi}

Guru sebagai fasilitator di lapangan dalam proses pembelajaran daring pasti akan selalu berhubungan dengan teknologi. Pembelajaran yang dilakukan secara online mengharuskan guru untuk mahir teknologi guna melaksanakan pembelajaran dan evaluasi kepada siswa. Dengan dilaksanakanya evaluasi pembelajaran maka seorang guru dapat memperoleh informasi yang valid tentang proses pembelajaran dan ketercapaian murid dalam mengikuti kegiatan belajar jarak jauh (Nuriyah, 2014). Evaluasi yang dilakukan secara online atau jarak jauh ini dapat digunakan dengan berbagai software, salah satunya dengan software website jeruq.com.

Respon guru terhadap website jeruq.com sebagai alat evaluasi pembelajaran memberikan respon yang baik. Saat dilakukan wawancara, guru menyebutkan bahwa dalam pembuatan soal menggunakan website jeruq.com dapat dikatakan cukup mudah meskipun ada beberapa langkah yang harus 
ditempuh. Guru tersebut juga menyebutkan bahwa website jeruq.com ini memiliki beberapa kelebihan diantaranya sebagai berikut.

1) hasil penilaian dapat langsung terlihat oleh guru dan siswa;

2) dapat mendeteksi kecurangan meskipun belum efektif;

3) terdapat fitur analisis soal yang sudah tersedia baik validitas, reliabilitas, daya beda, dan tingkat kesukaran;

4) terdapat fitur kelas dan dapat digunakan untuk diskusi.

Hasil penilaian yang dapat terlihat langsung oleh siswa dan guru setelah siswa selesai mengerjakan soal dapat memberikan transparansi nilai, sehingga siswa dapat termotivasi untuk lebih bersemangat mendapatkan nilai yang lebih baik sesuai dengan salah satu tujuan evaluasi. Evaluasi dapat mendorong siswa untuk lebih giat belajar secara terus menerus (Idrus, 2019).

Selain itu terdapat kelebihan lainnya dimana hasil jawaban siswa yang mengerjakan soal menggunakan website jeruq.com dapat diunduh dalam bentuk Ms. Excel. Data yang sudah tersimpan dalam Ms. Excel akan mudah diakses oleh guru dalam pengolahan nilai akhir evaluasi (Mutlasih, 2020).

Dengan kelebihan yang terdapat pada website jeruq.com, guru merasa cukup terbantu baik dari sisi keuangan maupun tenaga. Karena dengan adanya evaluasi online, guru tidak harus menghadirkan siswa ke sekolah dan evaluasi pembelajaran seiring diberlakukanya pembelajaran jarak jauh (Septiawan, 2020).

Guru tersebut menjelaskan selain beberapa kelebihan yang dimiliki, website ini memiliki beberapa kekurangan. Salah satu kekurangannya yaitu terdapat iklan yang dapat mengganggu konsentrasi siswa saat mengerjakan soal. Gangguan konsentrasi dapat menyebabkan siswa mudah beralih perhatian sehingga gagal untuk menyelesaikan sesuatu (Yuliana, 2014).

Kekurangan lainnya yang dimiliki oleh website jeruq.com adalah penilaian soal uraian singkat yang tidak dapat digunakan secara efektif karena hanya terpaku pada satu kunci jawaban. Soal uraian singkat yang dapat digunakan pada website jeruq.com harus soal yang memiliki satu jawaban, bukan yang banyak jawab. Agar siswa tidak ada yang disalahkan meskipun jawaban yang ia jawab merupakan jawaban yang benar, karena sistem penilaian yang otomatis sesuai satu kunci jawaban yang dimasukan pada website jeruq.com.

Berbagai kendala dan masalah yang dihadapi saat pembelajaran ataupun penilaian yang dilakukan secara online pada masa pandemi covid-19, ada hikmah yang dapat ditemukan dan dirasakan yaitu adanya proses percepatan proses transformasi digital di Indonesia (Bafadal \& Triansyah, 2020). Sebelum adanya pandemi covid-19, proses pembelajaran menggunakan digital sudah mulai diterapkan saat era 4.o tetapi masih banyak yang merasa kesulitan dan sulit diterima. Tetapi dengan adanya covid-19 memberikan dampak yang luar biasa pada proses pendidikan di era 4.0 (Astuni, 2020).

\section{KESIMPULAN}

Berdasarkan hasil penelitian dan pembahasan dapat disimpulkan website jeruq.com dapat menjadi salah satu software yang direkomendasikan sebagai alat penilaian online. Tampilannya mudah digunakan dan dimengerti. Respon siswa dalam penggunaan website jeruq.com sebagai alternatif alat evaluasi sangat baik, siswa dapat langsung memperoleh hasilnya. Respon guru dalam penggunaan website jeruq.com sebagai alternative alat evaluasi terhadap siswa mempermudah dalam menganalisis soal, menghemat waktu dan mempercepat perolehan hasil. Sehingga website jeruq.com 
dapat dijadikan sebagai salah satu alat evaluasi pembelajaran dimasa pandemi Covid-19.

\section{REFERENSI}

Admin Jeruq.com. (2021). Jeruq.com. Diambil kembali dari Jeruq.com: https://www.jeruq.com/about

Arianti. (2017). Urgensi Lingkungan Belajar Yang Kondusif Dalam Mendorong Siswa Belajar Aktif. Didaktika Jurnal Kependidikan.

Astuni, N. K. (2020). Tantangan dan Peluang Pemanfaatan Teknologi Informasi dalam Pembelajaran Online Masa Covid-19. Cetta: Jurnal Ilmu Pendidikan. https://doi.org/10.37329/cetta.v3i2.452

Bafadal, M. F., \& Triansyah, A. (2020). Formulir Google: Penilaian Alternatif Pendidikan Fisik Sebagai Covid-19. Science Tech: Jurnal Ilmu Pengetahuan dan Teknologi.

Efendi, N. M. (2018). Revolusi Pembelajaran Berbasis Digital. Jurnal Pendidikan, Sosiologi dan Antropologi (UGM).

Furqon. (2014). Statistika Terapan untuk Penelitian. Bandung: Alfabeta.

Idrus, L. (2019). Evaluasi Dalam Proses Pembelajaran. Adaara, Jurnal Manajemen Pendidikan Islam.

Irawati, D. Y., \& Jonatan, J. (2020). Evaluasi Kualitas Pembelajaran Online Selama Pandemi Covid-19: Studi Kasus di Fakultas Teknik, Universitas Katolik Darma Cendika. Jurnal Rekayasa Sistem Industri.

Lestari, W. I., \& Putra, E. (2020). Efektivitas Pembelajaran Matematika Menggunakan Media Pemberian Tugas Google Form di Masa Pandemi Covid19. Laplace: Jurnal Pendidikan Matematika.

Mutlasih, B. (2020). Penerapan Aplikasi Google Classroom, Google Form, Dan
Quizizz Dalam Pembelajaran Kimia Di Masa Pandemi Covid-19. 11.

Nashiroh, D. (2014). Pengembangan Model dengan Pendekatan Kontekstual pada Materi Barisan dan Deret untuk Peserta didik SMP Terbuka Kelas IX. Yogyakarta: Skripsi. FPMIPA.

Ngafifah, S. (2020). Penggunaan Google Form Dalam Meningkatkan Efektivitas Evaluasi Pembelajaran Daring Siswa Pada Masa Covid19 di SD IT Baitul Muslim Way Jepara. Jurnal As-Salam $I, 123-144$.

Novita, D., \& Hutasuhut, A. R. (2020). Plus Minus Aplikasi Pembelajaran Daring Analisis Kesalahan Mahasiswa View Project. Retrieved from https://www.researchgate.net/publicati on $/ 341830562$

Nuriyah, N. (2014). Evaluasi Pembelajaran. 14.

Nurrita, T. (2018). Pengembangan Media Pembelajaran Untuk Meningkatkan Hasil Belajar Siswa. Misyikat.

Riyanto, G. P. (2021, 02 23). Jumlah Pengguna Internet Indonesia 2021 Tembus 202 Juta. Retrieved from Kompas.com: https://tekno.kompas.com/read/2021/ 02/23/16100057/jumlah-penggunainternet-indonesia-2021-tembus-202juta

Septiawan, F. (2020). Efektivitas Penggunaan Google Form Dalam Pembelajaran Daring Pada Mata Pelajaran Pemeliharaan Mesin Sepeda Motor Di Smk Negeri 1 Koba. 7.

Sianipar, A. Z. (2019). Penggunaan Google Form sebagai alat penilaian kepuasan pelayanan mahasiswa. Journal of Information System, Applied, Management, Accounting, and Research.

Suryanovika, C. (2020). Google Forms: An Assessment Tool Accommodating The Generation Z Students' Learning Needs. 
E-Structural.

https://doi.org/10.33633/es.v2i2.3257

Warif, M. (2019). Strategi Guru Kelas dalam Menghadapi Peserta Didik yang Malas Belajar. Jurnal Tarbawi, Jurnal Pendidikan Agama Islam, 39-55.

Wulandari, P., Maswani, \& Khotimah, H. (2019). Google Form Sebagai Alternatif Evaluasi Pembelajaran Di SMAN 2 Kota Tangerang. Prosiding Seminar Nasional Pendidikan FKIP. Universitas Sultan Ageng Tirtayasa.

Yuliana, S. (2014). Pengaruh Latihan Identifikasi Objek terhadap Peningkatan Konsentrasi Anak Tunagrahita Ringan di SPLB-C YPLB Cipaganti.JASSI_Anakku. 